\title{
EFISIENSI ENERGI RUANG RAWAT INAP BANGUNAN RUMAH SAKIT ISLAM YARSIS SURAKARTA
}

\author{
Ria Kurniawati ${ }^{1}$, Syafi'i $^{2}$, dan Mamok Suprapto ${ }^{3}$ \\ ${ }^{1}$ Mahasiswa Magister Teknik, Jurusan Teknik Sipil, Universitas Sebelas Maret Surakarta \\ ria_180290@yahoo.com \\ ${ }^{2}$ Dosen Magister Teknik, Jurusan Teknik Sipil, Universitas Sebelas Maret Surakarta \\ syafii_hn@yahoo.com \\ ${ }^{3}$ Dosen Magister Teknik, Jurusan Teknik Sipil, Universitas Sebelas Maret Surakarta \\ mamokuns@gmail.com
}

\begin{abstract}
ABSTRAK
Rumah sakit merupakan salah satu bangunan yang mengkonsumsi energi cukup besar. Strategi menentukan cara mengurangi penggunaan energi dan mengurangi biaya operasional rumah sakit seperti ruang rawat inap dilakukan supaya dapat meningkatkan energi terutama energi listrik menjadi lebih efisien, yaitu dengan melaksanakan audit energi. Penggunaan energi gedung terbesar salah satunya yaitu sistem AC sebesar $60 \%$ dan sistem pencahayaan 20\%. Evaluasi efisiensi energi diarahkan ke sistem AC kemudian pencahayaan untuk penghematan energi gedung. Tahapan awal dengan mengevaluasi penggunaan energi menggunakan Intensitas Konsumsi Energi (IKE). Ruang rawat inap gedung Rumah Sakit Islam Yarsis Surakarta yang menggunakan pencahayaan terbatas dengan hasil IKE yaitu $36,13 \mathrm{kwh} / \mathrm{m}^{2} /$ bulan termasuk kategori sangat boros. Tahapan selanjutnya menggunakan Software Autodesk Ecotect dengan pemodelan dari simulasi pencahayaan ruangan. Tiga skenario energi bangunan seperti penambahan ventilasi, jendela, dan lampu kemudian dilakukan simulasi. Hasil simulasi ecotect yang sesuai dengan SNI 02-6575-2001 standar pencahayaan yaitu skenario tiga yang menggunakan penambahan ventilasi, jendela, dan lampu yang mendapatkan hasil rata-rata 250 Lux. Menghemat energi tidak dengan cara mematikan semua lampu pada saat siang hari, namun membatasi tingkat pencahayaan dengan minimal standar ruang rawat inap yaitu 250 Lux. Pencahayaan merupakan salah satu faktor untuk menentukan efisiensi energi bangunan, selain pencahayaan konsumsi energi bangunan harus di perbaiki supaya bangunan RSI Yarsis Surakarta lebih efisien dari segi konsumsi energi dan pencahayaan.
\end{abstract}

Kata kunci: Efisiensi Energi, Intensitas Konsumsi Energi (IKE), Pencahayaan

\section{PENDAHULUAN}

Penggunaan energi pada bangunan menelan konsumsi 40\% total energi global (Kurnitski, 2013). Ketersediaan sumberdaya yang terbatas dan upaya pengurangan emisi global menuntut adanya pemanfaatan energi yang efisien. Evaluasi energi diperlukan guna mengetahui efektifitas dan efisiensi penggunaan energi. Evaluasi energi merupakan langkah awal dalam upaya pengurangan penggunaan energi (Runmei Zhang et al, 2013) Evaluasi energi bermanfaat sebagai sarana penting dalam mencapai tujuan kritis suatu organisasi dan meningkatkan kemampuan organisasi tersebut agar lebih kompetitif (effendi, 2016).

Bangunan merupakan salah satu pengguna energi terbesar, sedangkan energi listrik sangat penting dalam kehidupan sehari-hari. Konsumsi energi utama yaitu lampu, AC, dan alat elektronik lainnya. Rumah sakit salah satu gedung yang mengkonsumsi energi cukup besar, maka energi yang digunakan untuk operasional akan semakin besar. Rumah sakit adalah institusi pelayanan kesehatan masyarakat jangka panjang, sehingga perlu dilakukukan langkah strategis efisiensi energi.

Objek penelitian ini adalah ruang rawat inap gedung Rumah Sakit Islam Yarsis Surakarta yang hingga saat ini telah banyak mengalami perkembangan dan perubahan. Dengan adanya perkembangan dan perubahan tersebut, menjadikan RSI Yarsis Surakarta tidak memperhitungkan efisiensi energi bangunan. 
Berdasarkan observasi ruang terlihat gelap dibagian koridor dan cukup gelap di kamar rawat inap. Penelitian bertujuan pada efisiensi energi gedung dengan mengembangkan model komputer menggunakan model simulasi untuk menganalisa pencahayaan.

Kajian literatur mengenai efisiensi energi di bangunan gedung telah dilaksanakan. Lei Xu et. Al., 2016 dalam penelitiannya melakukan audit energi yang menggunakan metode lighting analysis. Kajian ini memberikan hasil berupa strategi dalam penghematan energi gedung. Sejalan dengan penelitian tersebut, penelitian efisiensi energi juga dilakukan dengan studi kasus bangunan gedung RSI Yarsis Surakarta menggunakan metode lighting analysis memanfaatkan software ecotect dengan objek penelitian adalah ruang rawat inap.

\section{METODE PENELITIAN}

Efisiensi energi berkaitan dengan pencahayaan bangunan dilakukan dengan observasi pengumpulan data dan menggunakan pemodelan komputer yaitu Software Ecotect. Pengumpulan data seperti jenis alat listrik dan daya terpasang (watt). Metode penelitian ini dengan simulasi komputasi dapat memprediksi pencahaayaan dalam simulasi energi bangunan.

\section{Intensitas Konsumsi Energi (IKE)}

Intensitas Konsumsi Energi (IKE) adalah istilah yang digunakan untuk menyatakan besarnya jumlah penggunaan energi tiap meter persegi luas kotor (gross) bangunan dalam suatu kurun waktu tertentu, yang dinyatakan dalam satuan $\mathrm{kWh} / \mathrm{m}^{2} /$ bulan. Gedung kantor dan bangunan komersial dapat mengacu kepada standar kriteria seperti pada Tabel 1

Tabel 1. Kriteria IKE Gedung ber-AC
\begin{tabular}{cc}
$\mathbf{I K E}$ & Kriteria \\
$\left.\mathbf{( k W h} / \mathbf{m}^{\mathbf{2}} / \mathbf{b u l a n}\right)$ & \\
\hline $4,17-7,92$ & Sangat Efisien \\
\hline $7,93-12,08$ & Efisien \\
\hline $12,08-14,58$ & Cukup Efisien \\
\hline $14,58-19,17$ & Agak Boros \\
\hline $19,17-23,75$ & Boros \\
\hline $23,75-37,5$ & Sangat Boros \\
Sumber: DEPDIKNAS Tahun 2004
\end{tabular}

Intensitas Konsumsi Energi (IKE) pada setiap ruangan dapat dihitung dengan menggunakan persamaan:

$$
I K E=\frac{P_{K}}{A}
$$

dengan IKE $=$ intensitas konsumsi energi $\left(\mathrm{kWh} / \mathrm{m}^{2} /\right.$ tahun $), \mathrm{P}_{\mathrm{K}}=$ konsumsi listrik total $(\mathrm{kWh}), \mathrm{A}$ $=$ luas area $\left(\mathrm{m}^{2}\right)$

\section{Pencahayaan}

Dalam Peraturan Menteri Pekerjaan Umum No.05/PRT/M/2007 kualitas ruangan yang baik dapat dilihat dari penataan ruangannya. Untuk mendapatkan ruangan yang nyaman ruangan harus didesain dengan mempertimbangkan persyaratan kenyamanan yang terkait salah satunya dengan pencahayaan. 
Pada SNI, tidak terdapat data fluktuasi pencahayaan matahari tahunan sehingga diambil data tingkat pencahayaan matahari secara seragam yaitu 10.000 lux. Tingkat pencahayaan minimum yang direkomendasikan untuk berbagai fungsi ruangan pada Tabel 2.

Tabel 2. Tingkat Pencahayaan Minimum yang direkomendasikan

\begin{tabular}{ccc}
\hline Bangunan & Ruangan & $\begin{array}{c}\text { Besar kuat penerangan } \\
\text { yang dianjurkan } \\
\text { (Lux) }\end{array}$ \\
\hline Rumah Sakit & Ruang Rawat Inap & 250 \\
\hline & Laboratorium & 500 \\
\hline Ruang Operasi & 300 \\
\hline Ruang Bersalin & 300 \\
\hline & Ruang Rehabilitasi & 250 \\
\hline
\end{tabular}

Sumber: SNI 03-6575-2001

\section{HASIL DAN PEMBAHASAN}

Kondisi bangunan gedung RSI Yarsis Surakarta terdiri dari beberapa gedung, dan penelitian ini dilakukan evaluasi energi pada ruang rawat inap pada gedung utama berada di lantai 3 gedung. Ruang rawat inap terdiri dari 10 kamar rawat inap, namun pencahayaan ruang perlu dilakukan karena area rawat inap pada siang hari tidak menggunakan pencahayaan buatan, sehingga perlu dilakukan evaluasi lebih lanjut. Simulasi penelitian ruang rawat inap dilaksanakan pada bulan Februari Tahun 2017, dan waktu simulasi pada jam 12.00.

\section{Intensitas Konsumsi Energi (IKE)}

Menghitung Intensitas konsumsi Energi (IKE) pada ruangan ber-AC berdasarkan data beban listrik seperti jenis beban peralatan listrik yang terpasang pada ruang rawat inap RSI Yarsis Surakarta, dapat dilihat pada Tabel 3.

Tabel 3. Beban Peralatan Listrik Ruang Rawat Inap RSI Yarsis Surakarta

\begin{tabular}{clccc}
\hline No. & Beban Listrik & $\begin{array}{c}\text { Kapasitas } \\
\text { (watt) }\end{array}$ & $\begin{array}{c}\text { Jumlah } \\
\text { (unit) }\end{array}$ & Total \\
\hline 1 & Lampu TLD Beadhead Lamp & 10 & 10 & 100 \\
\hline 2 & Lampu DL & 18 & 50 & 900 \\
\hline 3 & AC 2 PK & 1920 & 2 & 3840 \\
\hline 4 & AC 1,5 PK & 1170 & 8 & 9360 \\
\hline 5 & Exhaust fan & 40 & 14 & 560 \\
\hline 6 & Komputer & 100 & 2 & 200 \\
\hline 7 & Printer & 40 & 1 & 40 \\
\hline 8 & LED TV 24” & 50 & 10 & 500 \\
\hline 9 & Kulkas mini & 50 & 10 & 500 \\
\hline 10 & Pesawat Telepon & 15 & 12 & 180 \\
\hline 12 & Wifi server & 22 & 1 & 22 \\
\hline & & & & $\mathbf{1 6 2 0 2}$ \\
\hline
\end{tabular}


Diasumsikan jumlah jam pelayanan dalam 1 hari selama 24 jam dan faktor kebutuhan beban selama 7 hari kerja (30 hari) diasumsikan 100\%. Sehingga diperkirakan konsumsi energi ruangan ber-AC perhari pada ruang rawat inap sebesar:

$$
16,202 \frac{\mathrm{kW}}{\mathrm{hari}} \times 24 \mathrm{jam} \times 1,00=388,848 \mathrm{kWh} / \mathrm{hari}
$$

Dikali 30 hari (jumlah hari efektif dalam 1 bulan), sehingga konsumsi energi listrik perbulan ruang rawat inap sebesar:

$$
388,848 \frac{\mathrm{kWh}}{\text { hari }} \times 30 \text { hari }=11665,44 \mathrm{kWh} / \text { hari }
$$

Luas ruang ber-AC pada ruang rawat inap adalah $322,8691 \mathrm{~m}^{2}$, sehingga IKE ruang ber-AC adalah:

$$
11665,44 \frac{\mathrm{kWh}}{\text { hari }}: 322,8691 \mathrm{~m}^{2}=36,1306 \mathrm{kWh} / \mathrm{m}^{2} / \text { bulan }
$$

Nilai IKE ruang rawat inap ber-AC sebesar 36,1306 kWh/m2/bulan menurut gedung rumah sakit masuk dalam kategori sangat boros.

\section{Simulasi Energi Sistem Pencahayaan}

Penelitian ini melakukan pengamatan langsung dengan menggunakan alat ukur lux meter, dilakukan pada setiap titik gedung ditempatkan $75 \mathrm{~cm}$ di atas lantai. Titik-titik posisi pengambilan data dapat dilihat pada Gambar 1 .

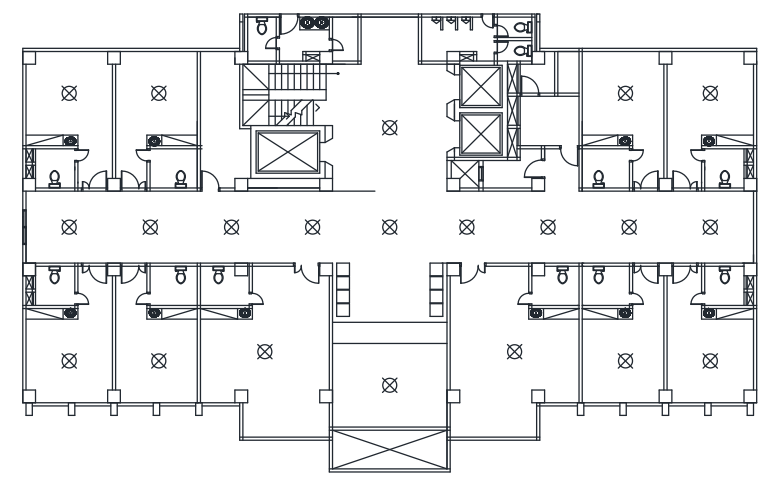

Gambar 1. Posisi Titik-titik Pengambilan Data

Hasil dari nilai tingkat pencahayaan menggunakan lux meter rata-rata di bawah 150 lux. Penelitian dilakukan pada jam 12.00 yang berarti matahari berada di atas, sehingga ruang rawat inap tidak banyak mendapatkan pencahayaan alami. Rumah sakit harus memiliki tingkat pencahayaan 240 lux meter, jadi berdasarkan SNI nilai tingkat pencahayaan di ruang rawat inap kurang memenuhi standar SNI.

Analisis pencahayaan alami menggunakan Software Ecotect dapat dilihat pada Gambar 2. Tingkat pencahayaan rata-rata berwarna ungu yang berarti memiliki kualitas kurang baik, dalam gedung dari atimur ke selatan memiliki kualitas baik yang berwarna merah, dan sedangkan pada sisi selatan gedung berwarna kuning yang memiliki kualitas sangat baik. 


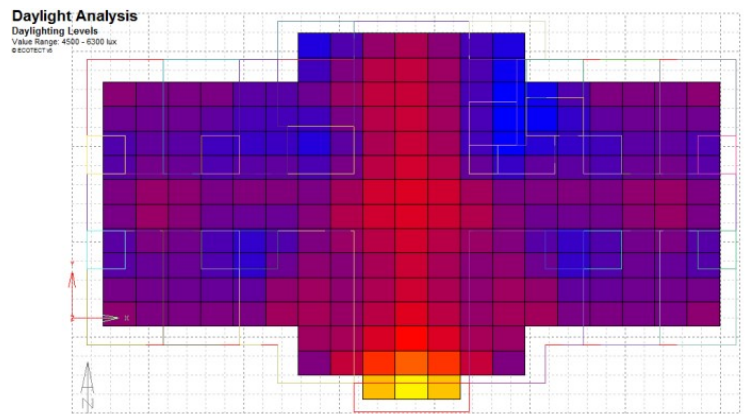

Gambar 2. Analisis Ecotect Pencahayaan Alami

Hasil pengukuran pencahayaan alami dan buatan di ruang rawat inap tidak memenuhi standar, maka dari hasil penelitian diberikan tiga skenario energi bangunan, dan dilakukan percobaan simulasi menggunakan pemograman ecotect, dapat dilihat pada Gambar 3.

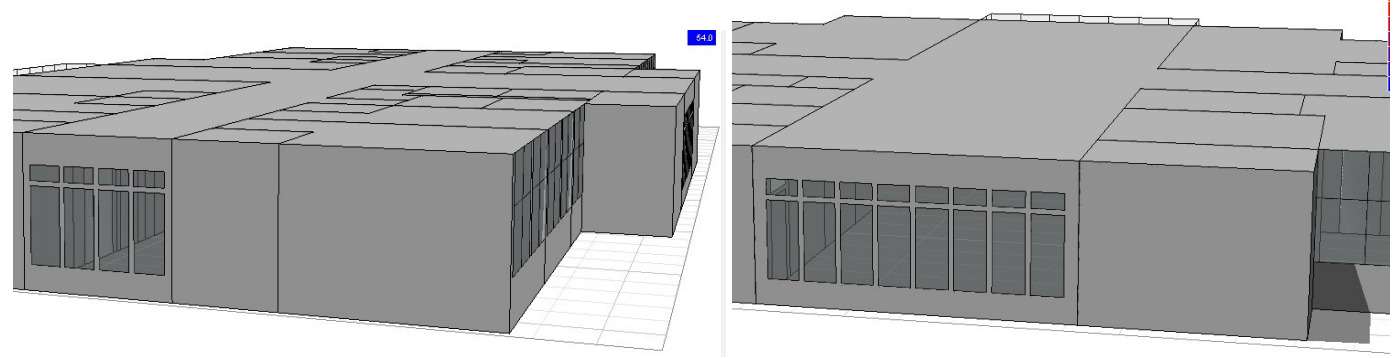

(a)

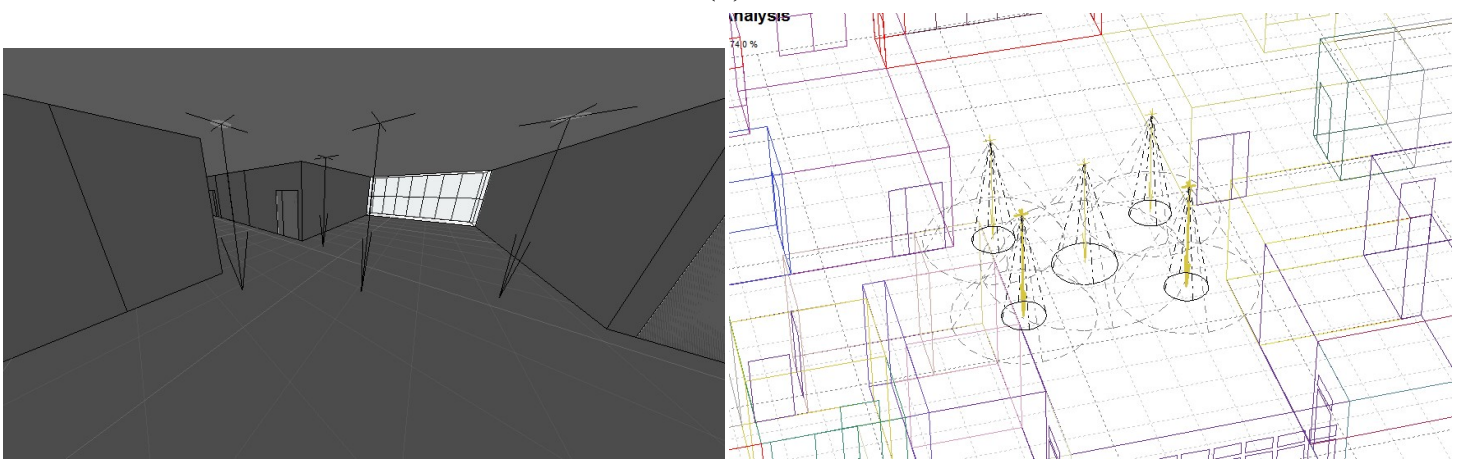

$\backslash(\mathrm{b})$

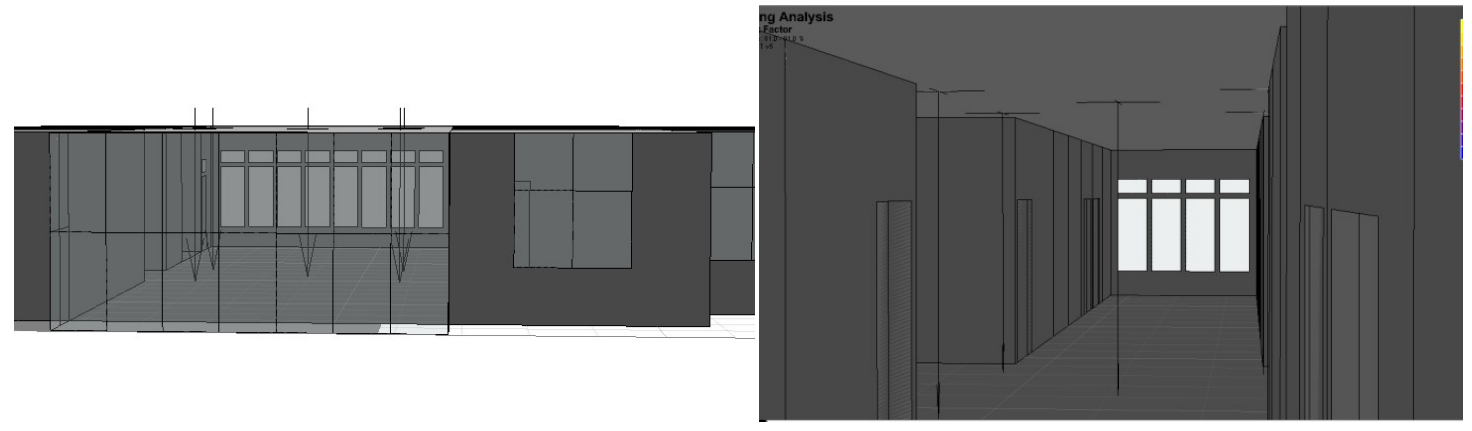

(c)

Gambar 3. (a) Skenario 1 (b) Skenario 2 (c) Skenario 3 
Skenario satu di sisi barat, utara, timur diberi penambahan ventilasi dan bukaan jendela. Skenario dua di bagian tengah bangunan diberi penambahan lampu, dan dilakukan perubahan letak lampu yang tepat sehingga tingkat pencahayaan baik. Skenario tiga di sisi barat, utara, timur diberi penambahan ventilasi dan bukaan jendela, kemudian ditambah kan lampu di bagian tengah bangunan.

Tiga skenario energi bangunan ruang rawat inap Rumah Sakit Islam Yarsis Surakarta dianalisis dengan simulasi ecotect, dapat dilihat pada Gambar 4.

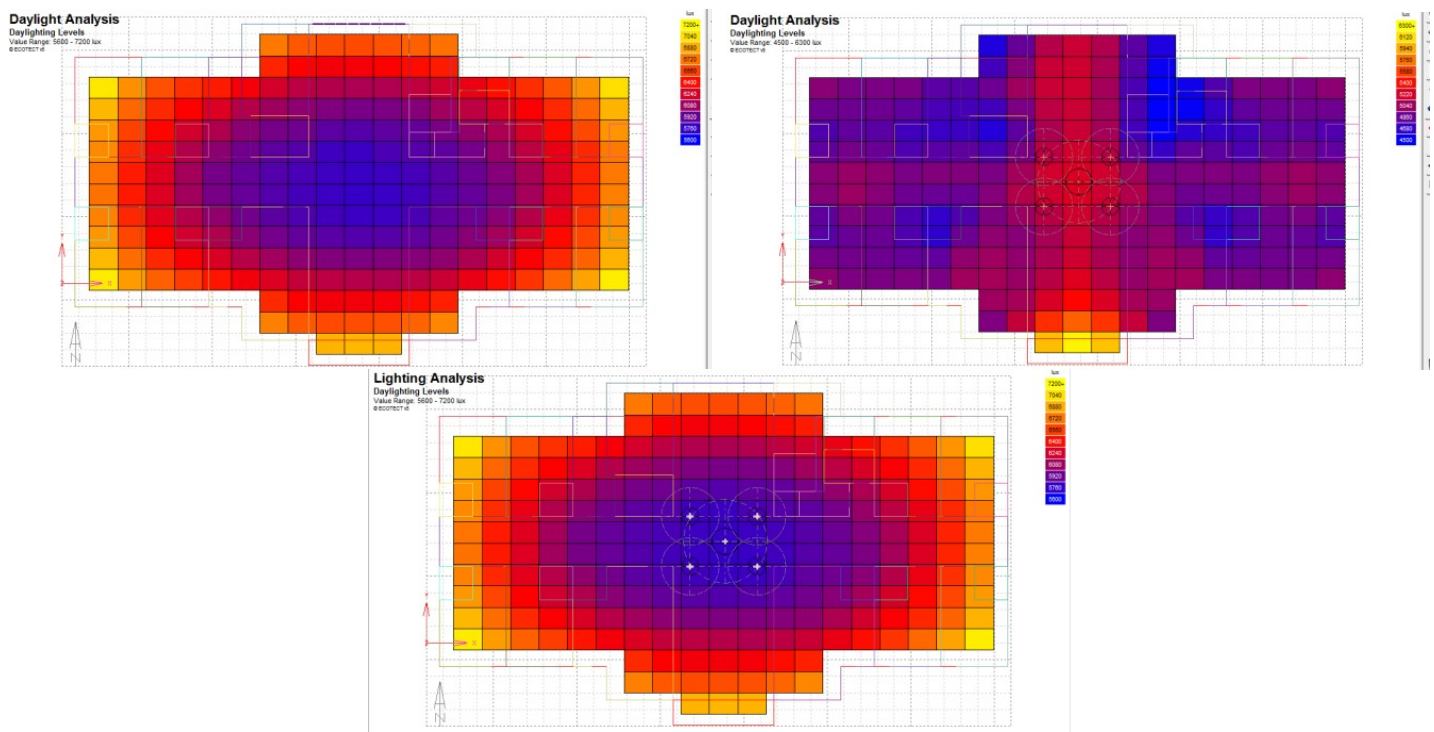

Gambar 4. Hasil Simulai Ecotect Pencahayaan Alami

(a) Skenario 1 (b) Skenario 2 (c) Skenario 3

Skenario 1 penambahan jendela dan ventilasi di sisi barat, utara, dan timur terlihat nilai lux meningkat, meskipun tidak sampai di tengah bangunan, dan sedangkan di selatan bangunan masih terlalu kuat. Skenario 2 penambahan pencahayaan buatan dengan menambah lampu di tengah ruang bangunan, sehingga tingkat nilai lux meningkat. Skenario 3 penambahan jendela dan ventilasi di sisi barat, utara, timur meningkatkan nilai lux, dan penambahan shading di sisi selatan mengurangi nilai lux terlalu tinggi, sedangkan penambahan lampu di tengah ruang bangunan meningkatkan nilai lux di bagian tengah bangunan.

\section{KESIMPULAN}

Hasil analisis nilai Intensitas Konsumsi Energi (IKE) ruang rawat inap Rumah Sakit Islam Yarsis Surakarta yaitu sebesar $36,1036 \mathrm{kWh} / \mathrm{m}^{2} /$ bulan. Besarnya nilai IKE masuk dalam kategori sangat boros.

Tiga skenario energi bangunan telah dilakukan simulasi ecotect dengan menggunakan tambahan ventilasi, jendela, dan lampu. Hasil simulasi ecotect yang sesuai dengan SNI 03-6575-2001 standar pencahayaan yaitu skenario tiga yang menggunakan penambahan ventilasi, jendela, dan lampu mendapatkan hasil ratarata 250 Lux. 
Pencahayaan merupakan salah satu faktor untuk menggunakan energi yang tepat dan efisien pada fasilitas penggunaan energi bangunan gedung tanpa mengurangi kenyamanan pengguna gedung RSI Yarsis Surakarta.

\section{Ucapan Terima Kasih}

Penulis mengucapkan terima kasih kepada Rumah Sakit Islam Yarsis Surakarta yang telah member dukungannya terhadap penelitian ini.

\section{REFERENSI}

Badan Standardisasi Nasional. SNI 03-6575-2001. Tata Cara Perancangan Sistem Pencahayaan Buatan Pada Bangunan Gedung. Jakarta.

DEPDIKNAS. 2004. Pedoman Pelaksanaan Konservasi Energi dan Pengawasan Di Lingkungan Depdiknas. Jakarta. Depdiknas.

Lei $\mathrm{Xu}$ et al. 2016. Lighting Energy Efficiency in offices under different control strategies. Journal Energy and Buildings. PP 127-139.

Peraturan Menteri Pekerjaan Umum No.05/PRT/M/2007. Pedoman Teknis Pembangunan Rumah Susun Sederhana Bertingkat Tinggi.

Kurnitski, Jaret. 2013. Cost Optimal and Nearly Zero-Energy Buildings. Springer.

Runmei Zhang et al. 2013. Case Study of BIM-Based Building Energy Evaluation. Proceedings of International Conference on Low-carbon Transportation and Logistics, and Green Buildings. Pp 787-798.

Effendi, Asnal. 2016. Evaluasi Intensitas Konsumsi Energi Listrik Melalui Audit Awal Energi Listrik Di Rsj.Prof.Hb.Saanin Padang. Jurnal Teknik Elektro ITP, Volume 5. No. 2; Juli 2016. 